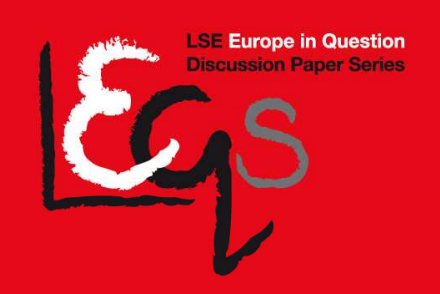

LSE 'Europe in Question’ Discussion Paper Series

\title{
The Reference Points of
}

\section{EU Judicial Politics}

Damian Chalmers \& Mariana Chaves

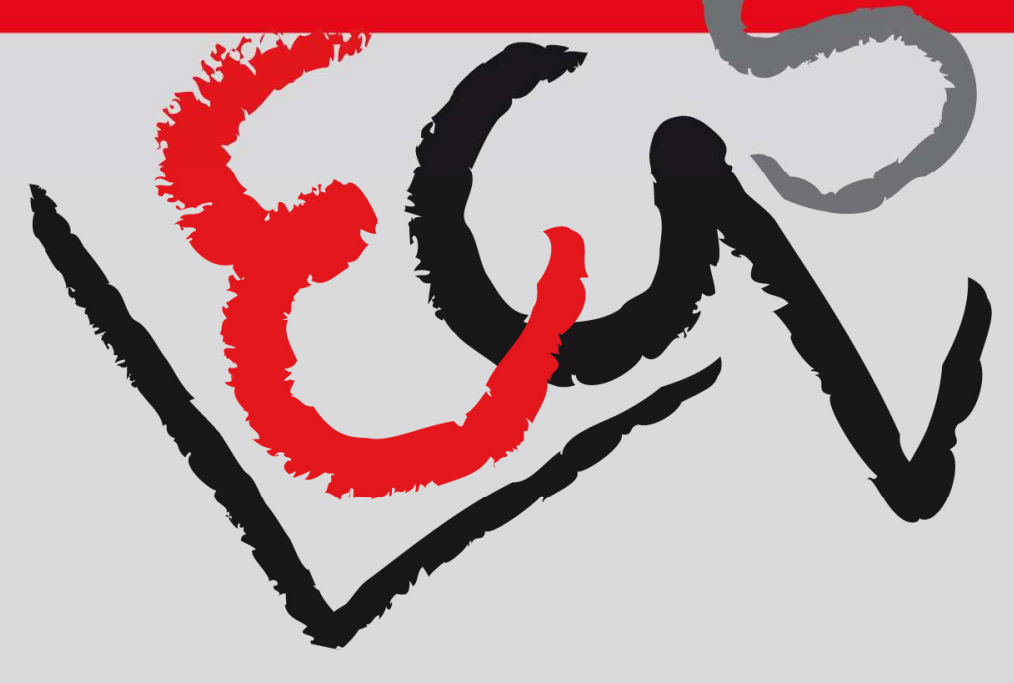




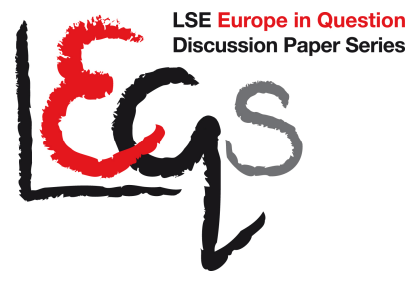

\section{Editorial Board}

Dr. Joan Costa-i-Font

Dr. Mareike Kleine

Dr. Jonathan White

Ms. Katjana Gattermann

All views expressed in this paper are those of the author and do not necessarily represent the views of the editors or the LSE.

(C) Damian Chalmers \& Mariana Chaves 


\title{
The Reference Points of
}

\section{EU Judicial Politics*}

\section{Damian Chalmers \& Mariana Chaves**}

\begin{abstract}
Explanations of the dynamics of EU judicial politics must also account for its incidence, namely when and in which sectors litigation of EU law and ECJ judgments occur. This incidence, it is suggested relies on a relationship between three arenas, those for norm-setting, litigation and judgments, as events in each of these arena conditions possibilities for action in the others. This paper analyses the relationship between these arenas through a study of all 2007-9 preliminary rulings and finds EU judicial politics characterised by two predominant dynamics. 'Patrol norms' dedicated to securing common policies give rise to low salient judgments dominated by transnational enterprise and national administration litigation. 'Thickly evaluative norms' are concerned with articulating certain values. Dominated by litigation by domestic undertakings and non-commercial actors, these norms generate the Court's salient judgments.
\end{abstract}

Keywords: Court of Justice; judicial politics; preliminary rulings

* This is a revised version of a paper that will be appearing in (2012) 19 Journal of European Public Policy (March issue).

** Damian Chalmers is Professor of European Union Law and Mariana Chaves a $\mathrm{PhD}$ candidate in European Union Law at the London School of Economics and Political Science.

Address for correspondence:

European Institute

Houghton St

London WC2A 2AE, UK

Email: d.chalmers@lse.ac.uk 


\section{Table of Contents}

1. Introduction

2. The Arenas of EU Judicial Politics 3

3. The EU Law-Maker and the Remit of the Judicial Game 5

(i) Judicial Politics a Confined and Unrepresentative Form of Integration

(ii) The Norms of Judicial Politics: Patrol Norms and Thickly Evaluative Norms

4. Litigants' Deployment of the Preliminary Reference Procedure 14

(i) Patrol Norms and Their Constituencies

(ii) Thickly Evaluative Norms and Their Constituencies

5. Preliminary Rulings and the Judicial Decision

6. Conclusion 


\section{The Reference Points of}

\section{EU Judicial Politics}

\section{Introduction}

Most recent accounts accept that no single narrative fully explains EU judicial politics (Alter 2009: 22-25; Jupille and Caporaso 2009; Kelemen 2011: 39-40). Research will accordingly need to consider the conditions under which one narrative holds rather than another. Comparison of patterns of litigation or adjudication across sectors or from different territories will go some way towards answering this. However, any comparison will also have to include analysis of the incidence of EU judicial politics, namely when and where it takes place. For the decision to enact a norm susceptible to judicial politics, to litigate or to refer a matter to the Court always involves a choice when other alternatives are available, and these choices set the conditions for judicial politics. Acceptance of such a relationship between the incidence and dynamics of EU judicial politics has two immediate implications. First, it necessarily problematises the significance of EU judicial politics. As we shall see, very few EU legal norms are susceptible to the traditionally understood form of judicial politics which emerges from national courts and ascends to the Court of Justice. Adjudication rates between EU legal sectors vary significantly (Chalmers 2000: 179) and litigation patterns are often significantly affected by external unpredictable factors (Cichowski 2007: 3234). Thinking about incidence not only helps us with the determinants of EU judicial politics but also informs us about the nature of the judicial beast. Secondly, it goes to the scope of inquiry. Any research into EU judicial politics 
must analyse the relationship between the adjudicated legal norm, the litigants/referring court and the decision of the Court itself as each is a precondition for the presence of the other. Neither the dynamics nor incidence of EU judicial politics can, thus, be considered without analysis of all three of these elements.

By analysing all preliminary rulings given in 2007-2009 through the lens of this relationship we find EU judicial politics to be sectorally confined, highly institutionally autonomous, and, in many ways, characterised a different mission from other parts of the integration process. It is, furthermore, dominated by two dynamics. The first is where the EU law-maker enlists the judiciary's help to secure common policies, typically those of the regulatory State. It is deployed to ensure the main protagonists meet their mutual commitments to one another. Litigation is dominated by constituencies influential in the law-making process and judgments tend not to be salient as the judicial role is about policing these commitments and finessing differences between these constituencies. The other is where EU legal instruments orient themselves more exclusively to the allocation of values rather than to securing common policies. These instruments are much rarer but generate a dynamic dominated by recursive case law and litigants, be they small industry or noncommercial actors, who are both domestic and enjoy traditionally limited influence within the law-making process. It is the bringing of the Court of Justice into this peculiar admixture of domestic disagreement, value iconography and redrawing of the boundaries of elite competition within this second process that has given the Court of Justice its prominence. 


\section{The Arenas of EU Judicial Politics}

The litigated norm, the identity of the litigant and the judgment itself are each indispensable to EU judicial politics. The litigated norm determines the level and form of judicial involvement and the Court's relationship with different constituencies. The litigants (and referring courts) provide the demand for judgments, frame the questions asked of the Court and provide expertise to the Court in the form of legal arguments and evidence as to how legal norms are experienced. The judgment is determinative of the dispute and constrains litigants and law-makers. Their interdependence leads to EU judicial politics being played out as a series of sequential interactions in three arenas:

- The decision by the law-maker, be it Treaty framer or Union legislature, to enact norms susceptible to judicial politics; ${ }^{1}$

- The decision by parties to litigate and to involve the Court of Justice through seeking a preliminary reference;

- The judicial decision itself.

The relationship between these arenas structures interactions in three ways. First, with the exception of the initial law-maker, prior outcomes from one arena structure possibilities in the other arenas. Secondly, most actors must factor into their decision-making a calculus of legal risk which anticipates responses to their decisions not only in the current arena but in the other two arenas. Judgments may provoke possible undesirable legal reforms or vexatious litigation. New laws may generate undesirable patterns of litigation and opportunities for judicial activism. Reckless litigation may induce legislative and judicial responses depriving litigants of current benefits.

\footnotetext{
${ }^{1}$ Law-maker is used to refer to both Treaty framing and secondary legislation in the rest of this article.
} 
Thirdly, as decision-making in each arena can never take place simultaneously with decision-making in other arenas, the mixture of prior outcomes and legal risk facing parties in each arena will always be different.

The calculus of choice for parties is not an abstract one. It is informed by the formal procedures set out in the Treaty on European Union (TEU) which constrain possibilities and set out incentive structures. The preliminary reference procedure in Article 267 Treaty on the functioning of the European Union (TFEU) is, in this regard, the epicentre of EU judicial politics. It and the enforcement procedure accounted in 2009 for $87.8 \%$ of the judgments delivered by the Court with it accounting for $49.9 \%$ (European Court of Justice 2010: 87). It places the Court of Justice at the forefront of the decisionmaking process and involves a wider range of constituencies as references emerge from litigation involving potentially any kind of party before any style of Union court or tribunal with the latter often seeking expertise on issues where there is no consensus about the content of EU law. By contrast, enforcement procedures against Member States are preceded by lengthy Commission-Member State negotiations with only a small proportion (in 2009 about $4 \%$ ) reaching judgment (European Commission 2010: 3). It is thus an arena of dispute settlement of last resort with the Commission winning 92.7\% of the cases in 2005-2009 (European Court of Justice 2010: 93). This leads to more salient and controversial issues being decided more frequently under the preliminary reference procedure. Thus, $73 \%$ of the judgments cited as significant during the period by the Court in its Annual Reports were preliminary rulings (European Court of Justice 2008: 11-50; European Court of Justice 2009: 11-53; European Court of Justice 2010:11-53).

The remainder of this article looks at how these interactions are played out through an analysis of all preliminary rulings given by the Court of Justice in the years 2007-9. There were 549 judgments generating 8981 observations. 
Some time after the completion of the area of freedom, security and justice and the 2004 enlargements for possible effects to be felt on the case law, the period is also sufficiently proximate to obtain reliable socio-economic data about the composition of the litigants.

\section{The EU Law-Maker and the Remit of the Judicial Game}

\section{(i) Judicial Politics a Confined and Unrepresentative Form of Integration}

EU law-makers have a choice whether or not to include justiciable entitlements that can be invoked in domestic courts and subject to Article 267 TFEU in their laws. The risk is that judges and litigants will interpret and apply these in ways that deviate from their preferences. Benefits are potentially two-fold. First, in the case of realisation of common goods and policies, judicial enforcement can help secure credibility of legislative commitments, which is, in turn, seen as necessary to prevent free-riding and as a precondition for policy effectiveness. Secondly, it can be used to institutionalise value-commitments which are articulated as deeply held but set out only generally in legal documents because of uncertainty and veiled disagreement as to their scope (e.g. civil liberties, liberal market values). The two roles are distinct. The former is concerned with the judiciary contributing to realising a densely institutionalised common policy as one cog in a wider settlement. With the latter, the judiciary is deployed to reinforce certain beliefsystems and to deter egregious behaviour by increasing the costs of violation be this financially or by naming and shaming (Howse and Teitel 2010: 131). The former is more prevalent in the EU. Its centre of gravity is still that of the regulatory State with little explicit role for in the direct allocation of values. 
The Reference Points of EU Judicial Politics

EU law-makers' interest in the judiciary is, thus, largely concerned with its first role of contributing to common goods rather than its latter one of reinforcing certain belief-systems.

The first implication of this is that EU law-makers would only exceptionally be interested in granting justiciable entitlements subject to Article 267 TFEU. A substitute procedure, the Article 258 TFEU enforcement procedure, secures legal commitments sufficiently effectively. Far more infringements, 2900 in 2009 (European Commission 2010: 3), are investigated than references made under Article 267 TFEU, 302 in 2009 (European Court of Justice 2010: 82). Compliance rates are reasonably high (Börzel 2001). It also carries less risk as it does not enfranchise new actors, such as domestic courts or litigants, with unpredictable preferences. 
Table 1: The Sectors of Litigation ${ }^{2}$

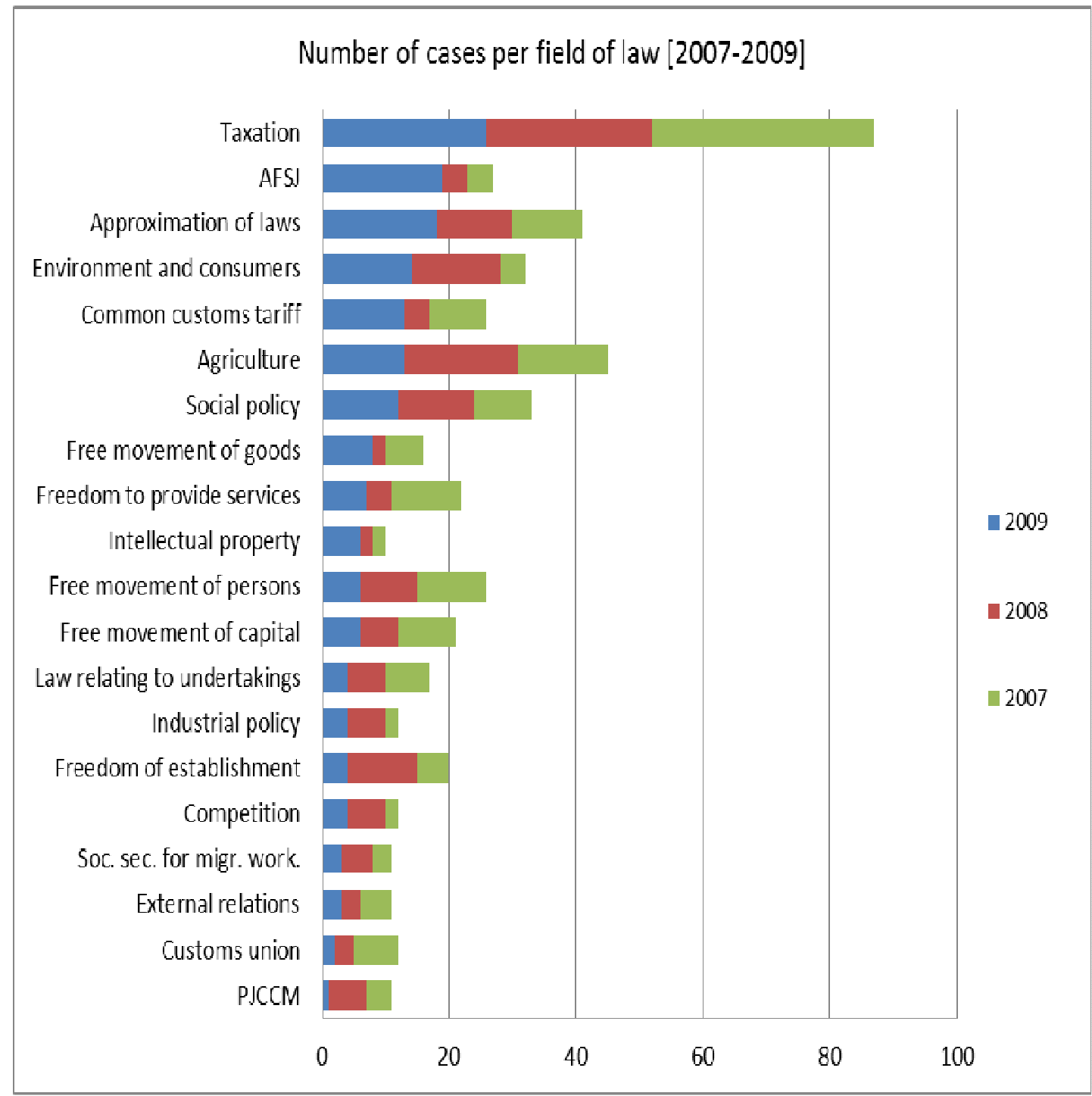

The rulings in this period reflect this. There are, according to the Court of Justice, 49 fields of legislative activity. During this period there were preliminary rulings in 35 of them. However, Table 1 illustrates that the number of rulings in most was minimal. In only 13 fields were there more than 15 judgments - a threshold of one reference for every 5.4 Member States per year. The situation is even more concentrated when one looks at where

${ }^{2}$ A large number of the titles are cryptic. 'Industrial policy' involves judgment on harmonisation of legislation on network industries; 'Law of Undertakings' concerns EU public procurement law; 'External Relations' involved association or neighbourhood agreements with non-EU States and invariable focussed on the rights of non-EU migrants under these. AFSJ is Area of Freedom, Security and Justice. PJCCM is Policing and Judicial Cooperation in Criminal Matters. 
litigation is clustered. If the economic freedoms are placed together on the grounds that these are interpreted in parallel manners and represented by single provisions in other jurisdictions (e.g. the commerce clause in the United States) and the common customs tariff and customs union are treated as a tax, over $80 \%$ of case law was in seven fields: the economic freedoms, harmonisation of laws, taxation, freedom, security and justice, environment, agriculture and social policy.

Secondly, Member States taking risks through significant steps in the integration process (e.g. accession, new EU competencies, ambitious Action Plans) would rarely wish to generate further volatility by allowing unpredictable constituencies to manage expectations over these through the preliminary reference procedure. This leads to little direct link between judicial integration and the integration process more generally. References are, thus, very stable across time, notwithstanding other developments in the integration process. The pattern of references set out in Table 1 follows an almost identical pattern to that of Brunell, Stone Sweet and Harlow in their work on preliminary rulings up to 2006, with the sole exception of the emergence of the area of freedom, security and justice as a significant field of referral (Brunell et al. 2008). Significant legislative programmes such as the 1992 programme or the Financial Services Action Programme do not lead to corresponding surges in referrals. In the case of the 1992 programme, Brunell et al. discovered that references moved from about $3.8 \%$ of references in the late 1980 's to $7.7 \%$ of references by the end of the $1990 \mathrm{~s}$, but this still accounted for only about 30 references per year or, put another way, two per year from each Member State (Brunell et al. 2008: 27). Similarly, the accession of the ten member States in 2004 has not yet led to an increase in preliminary rulings - with 254 in 2005 and 259 in 2009 (European Court of Justice 2010: 
86). ${ }^{3}$ Furthermore, there has been pre-emption of the preliminary reference procedure where a new field was anticipated to generate large numbers of references. Most notably, the establishment of the area of freedom, security and justice (AFSJ) at the Treaty of Amsterdam was accompanied by a limiting of the preliminary reference procedure to Member States who chose to opt-in for policing and judicial cooperation in criminal matters (PJCCM; Art. 35 $\mathrm{TEU})^{4}$ and a confining of the power to refer to courts against whose decisions there was no judicial remedy for all other matters connected to AFSJ (Art. 68 TEU). ${ }^{5}$

\section{(ii) The Norms of Judicial Politics: Patrol Norms and Thickly Evaluative} Norms

If law-makers only deploy the preliminary reference procedure when it offers comparative institutional advantages, this begs the question what sort of justiciable entitlement would confer such advantage. There are two: patrol norms and thickly evaluative norms. ${ }^{6}$

Patrol Norms: Actors dominant in the law-making process have no interest in the provision of entitlements which allow others to undermine their interests through litigation. However, most cannot fully rely on the centralised enforcement procedure to secure their interests insofar as the Commission has discretion over the use of this procedure. There is therefore an interest in entitlements which allow additional patrolling of commitments and the finessing of entitlements as preferences evolve (patrol norms). Examples

\footnotetext{
${ }^{3}$ The rulings given in 2005 were all given on references made before the date of accession. It is thus the most reliable date for comparing pre and post accession patterns.

${ }^{4}$ Article 35 TEU.

${ }^{5}$ Article 68 EC.

${ }^{6}$ Litigants are also given powers to challenge abuse by EU Institutions or significant regulatory or administrative powers before the General Court (e.g. competition and intellectual property). On litigant composition here see Harding and Gibbs 2005; Tridimas and Gari 2010.
} 
would be market access rights, rights of due process, rights to challenge administrative decisions which prohibit activity, tax, or refuse to grant financial entitlements. These are likely to be more prevalent in those sectors where deviance generates significant costs for other constituencies - be it denial of market access, significant distortions of competition between undertakings as a result of uneven application of regulatory burdens, illegal taxation or a failure to distribute financial entitlements - as these provide a motivation for patrol. Consequently, patrol norms are confined to EU secondary legislation. The EU Treaties are framework-treaties with few precise commitments with identifiable externalities to be patrolled. This is in stark contrast to sectors dominated by detailed legislation with precise commitments, notably the single market, agriculture, taxation, environment and consumer policy, and the area of freedom, security and justice insofar as it applies to judicial cooperation in civil matters.

Patrol norms are more closely associated with the first judicial role identified, namely that of securing common policies and the prevention of free-riding and institutionalisation of collective action necessary for these. However, to prevent disturbance of the legislative equilibrium the law-maker only grants such norms in narrowly confined circumstances and where their predominant utility is to parties dominant in the law-making process. Looking at Table 1, one would expect them to account for most of the litigation in the single market (approximation of laws, industrial policy and law of undertakings), agriculture, taxation (including customs union and common customs tariff), and some of the environmental litigation. If one includes all environmental and consumer rulings these sectors account for at best 295 judgments during the period. This is over half of the case law analysed, and therefore a predominant part of the Court's work. However, it is dwarfed by the respective legislation in the sectors. The three single market headings 
comprised, according to Eur-lex, a total of 1,417 Regulations and Directives; Environment 992 such instruments, and Agriculture 5,285. Referrals are, thus, very much the exception with the single market and agriculture averaging one ruling per 20 and 117 pieces of legislation respectively during the period.

Thickly evaluative norms: These are value-laden norms whose meaning and evaluative resonance cannot be understood in any strong way separately from the factual contexts in which they arise (Penner 2003). An example is discrimination. It is impossible to explain why offering an advantage to one party over another is egregious without placing it in a context which indicates why it is so. These norms challenge the balance about ethical commitments in most laws whereby the latter are only articulated at a certain generality allowing consensus to be maintained where there is deep disagreement. With thickly evaluative norms their heavy reliance on context entails that the initial legal commitments are too vague whilst implementation, by virtue of its being where the action takes place, is highly charged. Courts are thus, typically, deployed, first, because they receive information later than the lawmaker and are thereby better placed to consider the consequences of different applications of the norm (Rogers 2001). Secondly, judicial reasoning is well suited to thick evaluation as it is based on an application of norms to factual situations and consideration of the wider implications of this. Thirdly, the parameters of the dispute allow different parties to plead that the ambiguity concealing disagreement is not resolved beyond the factual scenario at the heart of the dispute.

Thickly-evaluative norms are more closely associated with the second role of the judiciary, the entrenching of certain belief-systems. They can be present in all sectors as no sector is either value-free or unmarked by deep contingency. They are, however, prevalent in sectors oriented exclusively around Treaty provisions (economic freedoms, competition, economic opportunities) as 
these provisions set out values to be realised rather than detailed programmes of actions. They are also present in sectors more explicitly concerned with the allocation of values - be they AFSJ and PJCCM insofar as they raise civil liberties and public order concerns, and much labour, environmental and consumer protection legislation insofar as they have resort to notions of fairness (labour or consumer law) or precaution (environmental law). These sectors all feature heavily in Table 1.

The prevalence of thickly evaluative norms is even more striking when one looks at the instruments deployed in the rulings. Regulations should be the most referred instrument. At the end of 2009, according to Eur-lex, there were 7717 Regulations in force and 1918 Directives; the circumstances in which Directives can be invoked in domestic courts are more constrained (Chalmers et al. 2010: 285-293) and Directives are deployed often because of the sensitivity of their content so there are higher political risks to judicial adventurism. However, the concern that it is problematic to resolve too much which leads Member States to agree Directives and Treaty provisions is the same as that which generates thickly evaluative legal norms. 
Table 2: Litigated Instruments

\begin{tabular}{|lcccc|} 
Primary/Secondary Law & $\mathbf{2 0 0 7}$ & $\mathbf{2 0 0 8}$ & $\mathbf{2 0 0 9}$ & $\mathbf{2 0 0 7 - 9}$ \\
Primary & 175 & 44 & 34 & 253 \\
Secondary & 50 & 22 & 17 & 30 \\
$\%$ & 173 & 152 & 167 & 492 \\
\hline Type of secondary Law & 50 & 78 & 83 & 70 \\
\hline Regulation & 2007 & 2008 & 2009 & $2007-2009$ \\
$\%$ & 49 & 42 & 69 & 160 \\
Directive & 33 & 27 & 40 & 33 \\
$\%$ & 84 & 98 & 95 & 277 \\
Decision & 57 & 63 & 55 & 58 \\
$\%$ & 0 & 2 & 1 & 3 \\
Framework Decision & 0 & 1 & 1 & 1 \\
$\%$ & 2 & 4 & 1 & 7 \\
Convention & 2 & 3 & 1 & 2 \\
$\%$ & 3 & 3 & 4 & 10 \\
Other & 2 & 2 & 2 & 2 \\
$\%$ & 9 & 6 & 3 & 18 \\
\hline
\end{tabular}

Table 2 shows therefore that Directives account for $58 \%$ of the secondary legislation invoked in references whilst Regulations account for only 33\%. A Directive is 6.7 times more likely to be referred than a Regulation. Similarly, Treaty provisions account for $30 \%$ of all referred cases, notwithstanding that, with the exception of Article 63 TFEU,7 all directly effective provisions date back to the original Treaty of Rome.

7 This provision on free movement of capital dates back to the Maastricht Treaty. 


\section{Litigants' Deployment of the Preliminary Reference Procedure ${ }^{8}$}

Although national courts formally make the references to the Court of Justice, often the reference will have been drafted by the litigants, and it is highly unusual, other than in criminal cases, for a national court to refer without one litigant pushing for it. Without such demand, the parties will simply settle, thereby taking the matter out of the hands of the courts. ${ }^{9}$ National courts have, thus, to be seen as gatekeepers in the process responding to litigant demand. Demand for references will only exist where one party wishes to reorient the legal settlement rather than make other choices such as asking the local court to apply EU law locally or looking for solutions which do not involve EU law. The comparative advantage of this choice will be governed by the relative return offered to litigants by the preliminary reference procedure compared to other institutional alternatives. Its value is less for parties with a wide variety of other avenues at their disposal for securing their preferences. By contrast, rulings become more attractive for parties marginalised within other venues (Alter and Vargas 2000; Slagter 2009). The value increases yet further if the reference opens up opportunity structures for parties where none existed before (Cichowski 2007; Alter 2009).

The preliminary reference procedure has three features which bear upon the litigants' calculation of advantage. It is time-consuming. The average period between the reference and Court of Justice judgment at the end of 2009 was

8 This article looked at litigants in the different sectors, whether they were domestic or transnational undertakings, domestic commercial actors, national administrations, private individuals or 'other actors', who were non-commercial actors most notably non-governmental organisations (ngos). Every judgment involves at least two parties and more where cases have been joined. In addition, the figures have to be read carefully. Many individuals are supported by ngos but this is often difficult to identify so there is some substitutability here. In addition, there is an over-representation of the State insofar as often it is the body against whom an EU law action must be brought.

${ }^{9}$ Nyikos found, for example, that over half of the Court rulings lead to settlement by the parties without the need for further national court intervention (Nyikos 2003). 
17.1 months (European Court of Justice 2010: 94), to which must be added time spent in the domestic legal system. It is ill-suited for those damaged by delay, e.g. those needing quick financial compensation or wishing to protect a market position. However, delay allows its use as a litigation strategy to weaken another litigant's position or to secure injunctive relief from a disliked domestic law, thus allowing the litigant a period of grace from the law pending resolution of the dispute (Rawlings 1993). This benefits actors with interests exclusively in one State as any injunctive relief will fully protect their position as it will apply across the whole of their market, the national territory. Secondly, the procedure is expensive. For those seeking only financial compensation, the returns have to be significant, therefore, to seek a referral. However, these returns may be calculated not simply in terms of the dispute in question but in also terms of opportunity costs. Parties with on-going relations governed by EU law have therefore a bigger interest in a reference than those in a one-off transaction. Finally, as a preliminary ruling resettles the legal settlement it attracts those who litigate to change the law to meet ideological preferences. Litigation offers high returns here as it does not require litigants to negotiate with other constituencies. Judgments of the Court of Justice are almost never overturned, and, in terms of profile for the litigants and entrenching particular belief-systems, rulings govern a large territory of nearly half a billion people.

Table 3: Domain of Litigation ${ }^{10}$

\begin{tabular}{|lcccc|}
\hline Type of Domain (percentage) & 2007 & 2008 & 2009 & $2007-2009$ \\
\hline Public & 62 & 51 & 47 & 53 \\
Private & 37 & 49 & 53 & 46 \\
Domestic & 64 & 60 & 60 & 62 \\
Transnational & 35 & 40 & 39
\end{tabular}
${ }^{10}$ A dispute was only classified as private if both parties were private actors. Similarly, a dispute
was only classified as domestic if both parties were domestic actors. 
Table 4: Litigating Constituencies

\begin{tabular}{|c|c|c|c|c|}
\hline Type of parties & 2007 & 2008 & 2009 & $2007-2009$ \\
\hline Firms & 88 & 83 & 107 & 278 \\
\hline$\%$ & 25 & 22 & 29 & 25 \\
\hline Multinationals & 36 & 48 & 48 & 132 \\
\hline$\%$ & 10 & 13 & 13 & 12 \\
\hline State & 147 & 150 & 127 & 424 \\
\hline$\%$ & 42 & 40 & 35 & 39 \\
\hline Individuals & 62 & 70 & 66 & 198 \\
\hline$\%$ & 18 & 19 & 18 & 18 \\
\hline \multirow[t]{2}{*}{ Other } & 17 & 25 & 18 & 60 \\
\hline & 5 & 7 & 5 & 5 \\
\hline Sector of activity (firms and multinationals) & 2007 & 2008 & 2009 & $2007-2009$ \\
\hline Agriculture/ fisheries & 9 & 13 & 9 & 31 \\
\hline$\%$ & 64 & 9 & 5 & 6 \\
\hline Industry & 62 & 49 & 83 & 194 \\
\hline$\%$ & 31 & 32 & 45 & 41 \\
\hline Services & 63 & 74 & 83 & 220 \\
\hline$\%$ & 45 & 49 & 45 & 46 \\
\hline Financial services & 2 & 8 & 4 & 14 \\
\hline$\%$ & 1 & 5 & 2 & 3 \\
\hline Not found & 4 & 7 & 7 & 18 \\
\hline$\%$ & 3 & 5 & 4 & 4 \\
\hline Industry subsectors & 2007 & 2008 & 2009 & $2007-2009$ \\
\hline Producers & 45 & 33 & 64 & 142 \\
\hline$\%$ & 38 & 22 & 47 & 40 \\
\hline Distributors & 47 & 44 & 39 & 130 \\
\hline$\%$ & 39 & 29 & 29 & 37 \\
\hline Retailers & 20 & 14 & 22 & 56 \\
\hline$\%$ & 17 & 9 & 16 & 16 \\
\hline \multirow[t]{2}{*}{ Not found } & 7 & 7 & 10 & 24 \\
\hline & 6 & 5 & 7 & 2 \\
\hline Size of companies (firms and multinationals) & 2007 & 2008 & 2009 & $2007-2009$ \\
\hline$\leq 1000$ employees & 33 & 27 & 19 & 79 \\
\hline$\%$ & 26 & 22 & 12 & 19 \\
\hline$\geq 1000$ employees & 28 & 33 & 40 & 101 \\
\hline$\%$ & 22 & 26 & 26 & 25 \\
\hline Not found & 68 & 65 & 97 & 230 \\
\hline$\%$ & 53 & 52 & 62 & 56 \\
\hline
\end{tabular}

These incentive structures are cross-cutting, and attract a wide variety of litigants across the different fields. Across almost any prism of analysis, it is impossible to find a general dominance by one particular constituency or one style of dispute. Commercial actors make up only $37 \%$ of litigants. There is a spread between transnational enterprises and domestic firms, large firms and 
smaller firms (less than 1,000 employees), the service, agricultural and industrial sectors. The different stages of the production process are also all well represented. In terms of the style of dispute there is also a fairly even division between disputes involving only domestic parties and those where one party is either a transnational actor or foreigner, albeit that most disputes are clearly domestic in nature. There is also a fairly even division between disputes which are exclusively between private parties and those which involve the State or public actors. Such heterogeneity makes it impossible to point to a single dynamic pushing forward the preliminary reference process. If transnational exchange accounts have to explain the heavy incidence of wholly domestic disputes and the heavy number of disputes involving the services sector when it is subject to limited transnational exchange, neofunctionalist accounts struggle to explain the wide array of actors and types of disputes present in the litigation.

However, one would expect these general figures to break down according to whether there is litigation of patrol norms or thickly evaluative norms as these would benefit different constituencies, provide different opportunity structures and the judgments enjoy a different function for the litigating parties. To ascertain whether this is the case, it is necessary, in the first place, to break the litigation patterns according to sectors.

\section{(i) Patrol Norms and Their Constituencies}

Insofar as patrol norms typically benefit constituencies dominant in the lawmaking process, it makes sense to analyse the take-up of references by the two parties most regularly dominant in the EU legislative process, transnational enterprises and national administrations. The value of the process is reduced for these by the possibility of institutional substitutes to secure their 
preferences - be it legislative amendment or, in the case of transnational enterprises, various forms of alternative dispute settlement. In the light of this and the financial and temporal costs of a reference, there seem only two circumstances when there is an incentive to seek a reference. The first is the rare scenario where one of these actors finds no institutional substitute available and the law is sufficiently entrenched, costly and distant from its preferences. The second is where there is no institutional substitute available and the actor is in an on-going relationship with other actors (e.g. national regulatory or fiscal authorities). In such circumstances, there is an open nature to costs or opportunity costs from misaligned laws that can make a reference seem cheap. 
Table 5: Parties Litigating in Different Sectors

\begin{tabular}{|c|c|c|c|c|c|}
\hline & Domestic firms & Multinationals & State & Individuals & Others \\
\hline Agriculture & 31 & 6 & 40 & 10 & 4 \\
\hline$\%$ & 34 & 7 & 44 & 11 & 4 \\
\hline Approximation of laws & 27 & 23 & 18 & 11 & 5 \\
\hline$\%$ & 32 & 27 & 21 & 13 & 6 \\
\hline AFSJ & 15 & 6 & 7 & 25 & 3 \\
\hline$\%$ & 27 & 11 & 13 & 45 & 5 \\
\hline Customs custom tariff & 15 & 10 & 26 & 2 & 0 \\
\hline$\%$ & 28 & 19 & 49 & 4 & 0 \\
\hline Competition & 7 & 6 & 5 & 1 & 5 \\
\hline$\%$ & 29 & 25 & 21 & 4 & 21 \\
\hline Customs Union & 5 & 7 & 11 & 1 & 0 \\
\hline$\%$ & 21 & 29 & 46 & 4 & 0 \\
\hline Environment \& consumers & 12 & 7 & 26 & 12 & 7 \\
\hline$\%$ & 19 & 11 & 41 & 19 & 11 \\
\hline External relations & 2 & 1 & 10 & 9 & 0 \\
\hline$\%$ & 9 & 5 & 45 & 41 & 0 \\
\hline Free movement of capital & 8 & 3 & 21 & 10 & 0 \\
\hline$\%$ & 19 & 7 & 50 & 24 & 0 \\
\hline Free movement of goods & 12 & 3 & 11 & 4 & 3 \\
\hline$\%$ & 36 & 9 & 33 & 12 & 10 \\
\hline Free movement of persons & 4 & 1 & 23 & 22 & 2 \\
\hline$\%$ & 8 & 2 & 44 & 42 & 4 \\
\hline Freedom of establishment & 8 & 5 & 18 & 6 & 4 \\
\hline$\%$ & 20 & 12 & 44 & 15 & 10 \\
\hline Freedom to provide services & 10 & 4 & 20 & 6 & 4 \\
\hline$\%$ & 23 & 9 & 45 & 14 & 9 \\
\hline Industrial policy & 7 & 6 & 10 & 1 & 2 \\
\hline$\%$ & 27 & 23 & 38 & 4 & 8 \\
\hline Intellectual property & 6 & 9 & 1 & 1 & 3 \\
\hline$\%$ & 30 & 45 & 5 & 5 & 15 \\
\hline Law relating to undertakings & 17 & 0 & 14 & 1 & 3 \\
\hline$\%$ & 49 & 0 & 40 & 3 & 9 \\
\hline PJCCM & 0 & 0 & 9 & 11 & 2 \\
\hline$\%$ & 0 & 0 & 41 & 50 & 9 \\
\hline Social policy & 9 & 5 & 22 & 28 & 4 \\
\hline$\%$ & 13 & 7 & 32 & 41 & 6 \\
\hline Social security for migrant workers & 1 & 0 & 11 & 10 & 0 \\
\hline$\%$ & 5 & 0 & 50 & 45 & 0 \\
\hline Taxation & 41 & 29 & 88 & 10 & 6 \\
\hline$\%$ & 24 & 17 & 51 & 6 & 3 \\
\hline
\end{tabular}


Table 5 shows that litigation by transnationals is concentrated in the single market (approximation of laws, industrial policy and intellectual property) and fiscal fields (taxation, customs union and common customs tariff). The incidence is in all cases significant with transnationals accounting for $35 \%$ of non State parties. It is impossible to argue that this is because these sectors are transnational in nature. Taxation, for example, largely concerns value added tax (VAT), a tax governing a far larger proportion of economic activity than transnational trade. Instead, the pattern of litigation fits the thesis of a transnational society which generates its own transnational rules of the game and systems of dispute settlement which are then policed by transnational actors (e.g. Fligstein and McNichol 1998; Stone Sweet and Caporaso 1998; Fligstein 2008). However, the data also shows the limits of the transnational society thesis. Even in the sectors where transnational actors are prevalent they rarely predominate. The generalisability of legal entitlements enables other actors to invoke them and has given rise to a significant parallel dynamic in most of these sectors in which local industry litigates these norms domestically. However, the most telling limitation is the low levels of transnational litigation. Notwithstanding over 1400 pieces of legislation, the single market accounted for only 21 referrals per year of which transnationals comprised about one quarter of the litigating parties. It is simply something that is rarely used.

The involvement of national administrations is high in almost all sectors. In large part, this is because the State is necessarily the target of EU litigation. However, as defendants, national administrations could always settle if they did not wish a referral. Moreover, it cannot be excluded that they provoke them. If a national administration wants to reorient the legal settlement within its territory it may regulate or tax at the perimeters of the formal competencies granted by EU law in order to align it with its domestic 
preferences. This would most likely trigger a reference where it imposes significant costs or sufficiently restricts opportunities for that State's subjects. In such circumstances, both constituencies have an interest in the ruling. The administration wishes to secure legal certainty for a new prerogative whilst parties subject to an on-going long-term fiscal or regulatory relationship with the administration can see unending costs unless they secure a favourable ruling.

Table 5 shows, therefore, that national administration involvement is over $40 \%$ in sectors where EU law has extended national regulatory, fiscal and penal capacities - be this environment law (Héritier et al. 1996; Anderson and Liefferink 1997:10-35), VAT in the field of taxation (Terra and Wattel 2008: 120) or penal law (Chaves 2011: chapter 4). It is also high where EU law grants the State most control over private activities - be it be the extraction or grant of resources to individuals (agriculture, taxation), entry or expulsion of the territory (external relations, free movement of persons), removal of liberty (PJCCM) or significant and costly regulation (environment and consumers). By contrast, it is surprisingly low in fields where the administration would seem the natural defendant (approximation of laws, area of freedom, security and justice, free movement of goods) but these qualities are not present.

\section{(ii) Thickly Evaluative Norms and Their Constituencies}

As thickly evaluative norms concern situations whose dimensions are difficult to anticipate, their use is rarely confined to a limited range of litigants. This brings two types of litigant into the process largely absent from the referral of patrol norms: those wishing to use litigation to change the general legal settlement for ideological reasons and domestic traders wishing to use EU law to suspend - initially through interim relief and then through a ruling - a 
disliked national law. In both instances, the value of the procedure is increased by the possible unavailability of institutional substitutes as there are strong possibilities that neither will have significant influence in either the domestic or EU law-making processes. However, alongside this, one would expect a slight under-representation from those constituencies who are the targets of the norms in question. These might be unhappy with the EU legal norms, but as their unhappiness is with EU law not domestic law, there is no easy possibility of interim relief. A referral, thus, brings no immediate relief for them but is a costly exercise with the risk that the Court will not accede to their preferences but will provide a ruling that exacerbates the situation.

Table 5 shows sectors characterised by thickly evaluative norms - the economic freedoms, competition, social policy, environment and consumer policy, area of freedom, security and justice - are all marked by litigant diversity. This cannot be explained by reference to affinities of the sector. Competition, free movement of services and freedom of establishment all require, in principle, the presence or imminence of transnational trade for their instigation. Yet, in all cases, domestic enterprise litigation is higher than that of transnationals. A further feature of these fields is that all are marked by high numbers of domestic litigants - be it commercial or non-commercial. A consequence is if thickly evaluative norms may be transnational in provenance they are deployed in disputes which are highly local in substance and go, in the first place, to revision the domestic polity. The other feature of note is litigant diversity involving both commercial and non-commercial actors is present in all these sectors, including the economic freedoms. Litigation has moved these away from being simply market provisions to the point where they are being deployed by non-commercial actors to secure broader entitlements from domestic administrations. Finally, there is the under-representation of certain classes of litigant who are disadvantaged by 
the reference procedure. Two sectors, Social Policy and Environment and Consumer, are characterised by low commercial activity, notwithstanding that these will often be defendants and will bear the brunt of aggressively expanding equal opportunities or consumer protection law. Put simply, this is because there is no evidence of their acting as plaintiffs in this field or of engineering a dispute to push back the law here.

\section{Preliminary Rulings and the Judicial Decision}

The Court's interest in its judgments is to secure authority for itself and its work. However, there are a wide variety of constituencies it has to satisfy. To be sure, this includes litigants and governments. It is, thus, more likely to accept a point argued by a greater number of States or by parties privy to the dispute (Granger 2004; Carrubba et al. 2010). More general literature on courts suggests reputation within legal and judicial peer communities weights particularly heavily on these (Miceli and Cosggel 1994; Schauer 2000). The views of senior courts and legal specialists matter (Stein 1981; Schepel and Wesselink 1997; Alter 2009: 63 et seq.). However, courts' wider authority with their subjects is dependent on their arguments appearing to be legally rather than politically reasoned (Gibson et al. 2005). There is, thus, a premium in making arguments perceived by these constituencies as legally appropriate, intellectually cogent and principled. Prior case law weighs particularly heavily on the decision-making of the Court (Komárek 2011: chapters 6 and 7).

To mediate between these interests in a legally reasoned manner, the Court adopts particular roles in relation to types of dispute. These provide a template which settles other parties' expectations of what the Court will do 
and what they can ask of it. They also allow the Court some autonomy as it does not have to make the case anew each time. The role of the Court is shaped, in the first place, by what norms it is asked to adjudicate and, in the second place, by whom it is asked to adjudicate these norms for, namely the parties in the dispute and significantly affected third parties.

Disputes involving patrol norms invariably regard challenges to the exercise of regulatory, fiscal and penal capacities by national administrations on the basis that these have breached very specific commitments rather than any deep-seated values. This typically calls the Court into two types of role. The first, that of welfare constitutionalism, asks courts to contribute towards helping government to secure collective goods set out or respected by EU law (ie regulation of externalities, collection of taxes, security). This role may involve redirecting other arms of government but there is a concern not to disrupt the provision of these goods or subvert the institutional processes realising these (Barber 2003; Murphy 2007). The second role derives from the Court having to secure respect for the patrol norms. This typically brings into play a balancing role in which the Court seeks to ensure that neither the litigated interests nor the public good in question are unduly prejudiced. Neither role calls for the Court to make judgments with a high salience. It is not asked to develop strong autonomous lines of case law or to mark out a striking judicial position which has wider social, economic or political consequences. Furthermore, the nature of patrol norms is that they impose obligations and entitlements on a limited range of parties so only a small number will be directly affected by a judgment (Chalmers et al. 2010: 285312).

With thickly evaluative norms, the wider variety of parties privy to disputes pushes the Court to have a more strongly assertive role. Litigation by a wide range of constituencies can have destabilising effects on the law as a 
cacophony of voices all claim it means different things unless the Court establishes a strong line of case law which is sufficiently clear to align preferences. There are further pressures. Often such norms also serve to protect diffuse interests which are traditionally poorly served by majoritarian institutions (e.g. minorities, women, consumers, the environment, foreign traders or poorly organised commercial interests). This leads to both an absence of detailed legislative direction and to arguments for a stronger judicial role to rectify this representative deficit on the basis not only that this is desirable (Maduro 1998) but that it is a feature of judicial tradition and one of the bases for public support for the judiciary (Vanberg 2001; Friedman 2003).

Table 6: Salient Judgments

\begin{tabular}{|c|c|c|c|}
\hline Field & Number of Cases per Field & $\begin{array}{l}\text { Number of } \\
\text { Salient } \\
\text { Judgments }\end{array}$ & $\begin{array}{c}\text { Percentage } \\
\text { of Salient } \\
\text { Judgments }\end{array}$ \\
\hline Taxation & 87 & 6 & 6.90 \\
\hline Agriculture & 45 & 4 & 8.89 \\
\hline Approximation of laws & 41 & 13 & 31.71 \\
\hline Social policy & 33 & 16 & 48.48 \\
\hline Environment \& consumers & 32 & 11 & 34.38 \\
\hline AFSJ & 27 & 9 & 33.33 \\
\hline Customs custom tariff & 26 & 0 & 0 \\
\hline Free movement of persons & 26 & 11 & 42.31 \\
\hline Freedom to provide services & 22 & 11 & 50 \\
\hline Free movement of capital & 21 & 8 & 38.10 \\
\hline Freedom of establishment & 20 & 10 & 50 \\
\hline Law relating to undertakings & 17 & 5 & 29.41 \\
\hline Free movement of goods & 16 & 8 & 50 \\
\hline Competition & 12 & 6 & 50 \\
\hline Customs Union & 12 & 1 & 8.33 \\
\hline Industrial policy & 12 & 2 & 16.67 \\
\hline External relations & 11 & 4 & 36.36 \\
\hline PJCCM & 11 & 6 & 54.55 \\
\hline Social security for migrant workers & 11 & 2 & 18.18 \\
\hline Intellectual property & 10 & 5 & 50 \\
\hline
\end{tabular}


One would therefore expect sectors dominated by thickly evaluative norms to give rise to a higher percentage of significant judgments than those dominated by patrol norms. Table 5 suggests that sectors characterised by such norms tend to give rise to more salient judgments. All the economic freedoms, other than free movement of capital, and competition have $40 \%$ or more of their rulings characterised as significant. Sectors governed by EU secondary legislation move along a scale. At one end are two sectors, social policy and PJCCM, heavily informed by thickly evaluative norms for which $48 \%$ and $55 \%$ of their judgments are deemed significant during this period. There are, then, a number of sectors - approximation of laws, industrial policy and environment and consumers - where about one third of the rulings are deemed significant. These are sectors where issues of mutual commitment, and thus patrol norms, are prevalent. However, regulatory or fundamental rights norms arise which are thickly evaluative in nature, politically salient, and generate interpretive uncertainty to be resolved by judges. Finally, there are those sectors, taxation and agriculture, dominated by patrol norms with few thickly evaluative norms which have very low percentages of significant rulings.

There is, however, a further reason for the distinction in salience, and this goes to the feedback dynamics surrounding Court judgments. The sectors (economic freedoms, competition, intellectual property, social policy) in which there are the highest proportion of significant judgments are also those characterised by heavy lines of case law. This is paradoxical as one would expect prior rulings would limit the scope for significant subsequent rulings which would simply follow in their footsteps.

However, with patrol norms, the presence of institutional substitutes for the affected constituencies means that, irrespective of the voting requirements in the Council, there is frequent legislative revision of adjudicated instruments. 
The centrepiece of EU tax law litigation, the Sixth VAT Directive, was for example, prior to its recasting in 2006 revised thirty one times in its thirty years. ${ }^{11}$ Such a shifting legal settlement relativises the importance of any judgment and also increases the possibility of legislative over-rule.

As thickly evaluative norms enfranchise or adversely affect a wide number of constituencies, judgments touch more directly many more parties not privy to the dispute. For many of these the relative return of preliminary references is high as there are few institutional substitutes for securing their preferences. Even if the original constituencies are satisfied with the new legal settlement set out in a judgment, these 'new entrants' who are now possibly empowered by it will wish to now use the reference procedure that more fully secures their preferences. The referral process, thus, generates its own feedback loops where case law leads to further litigation which in turn provokes more rulings and so on. However, in each case as it was new constituencies making their own demands, these were often quite significant in political economic terms.

\section{Conclusion}

The dual dynamics of patrol norms and thickly evaluative norms reveals both the significance and challenges of both the Court of Justice and EU law. The low salience of patrol norms and their use by a narrow range of constituencies raises issues about capture of the judiciary. Thickly evaluative norms explain the salience of the Court of Justice. They draw it into the allocation of values and amplification of beliefs in charged circumstances that are simultaneously

\footnotetext{
11 Directive 77/388 on the harmonisation of laws relating to turnover taxes, OJ 1997, L 145/1. For the list of amendments see http://europa.eu/legislation_summaries/other/l31006 en.htm\#AMENDINGACT <accessed 1 April 2011>
} 
strongly embedded in local contexts and ones that local settlements have been unable to resolve consensually. However, they occur in sectors which represent a small proportion of total EU law, are institutionally distinct from the other processes of EU law and constitute a very different quality of integration from the rest of the EU institutional settlement, namely securing belief systems rather realising common policy. Even if the Union were to have such a role, this still begs the question why it is the Court of Justice that should have a monopoly over this, and whether, if we started anew, the central values we should wish the Union to secure are an ad hoc mixture of economic liberalism, equal opportunities and labour rights. 


\section{References}

Alter, K. J. and Vargas, J. (2000) 'Explaining Variation in the Use of European Litigation Strategies: European Community Law and Gender Equality Policy' Comparative Political Studies 33(4): 452-482.

Alter, K. J. (2009) The European Court's Political Power, Oxford: Oxford University Press.

Anderson, M. S. and Liefferink, D. (eds) (1997) European environmental policy; the pioneers, Manchester: Manchester University Press.

Barber, S. (2003) Welfare and the Constitution, Princeton, NJ: Princeton University Press.

Börzel, T. (2001) 'Non-Compliance in the European Union. Pathology or Statistical Artefact?' Journal of European Public Policy 8(5): 803-824.

Brunell, T. L., Stone Sweet, A., and Harlow, C. (2008) 'Litigating the Treaty of Rome: The European Court of Justice and Articles 226, 230, and 234', New Modes of Governance Project (NEWGOV), http://www.eu-newgov.org/datalists/deliverables_detail.asp?Project_ID=26.

Carrubba, C. J., Gabel, M., and Hankla, C. (2008) 'Judicial Behavior Under Political Constraints: Evidence from the European Court of Justice' American Political Science Review 102(4): 435452.

Chalmers, D. (2000) 'The Positioning of EU Judicial Politics within the United Kingdom' West European Politics 23(4): 169-210.

Chalmers, D. (2005) 'The Court of Justice and the Constitutional Treaty’ CON I-41: 428-453.

Chalmers, D. Davies, G. \& G. Monti, G. (2010) European Union Law, 2nd Edition, Cambridge, Cambridge University Press.

Chaves, M. (2011) European criminal law: reshaping criminal justice across the European Union? (forthcoming) Ph.D. dissertation, London: London School of Economics and Political Science.

Cichowski, R. (2007) The European Court and Civil Society: Litigation, Mobilisation and Governance, Cambridge: Cambridge University Press.

European Commission (2010) 27th Annual Report on the Monitoring of the Application of EU Law, COM (2010) 538 final.

European Court of Justice (2008) Annual Report of the European Court of Justice 2007, Luxembourg: Court of Justice.

European Court of Justice (2009) Annual Report of the European Court of Justice 2008, Luxembourg: Court of Justice.

European Court of Justice (2010) Annual Report of the European Court of Justice 2009, Luxembourg: Court of Justice.

Fligstein, N. and McNichol, J. (1998) 'The Institutional Terrain of the European Union', in W. Sandholtz and A. Stone Sweet (eds), European Integration and Supranational Governance, Oxford: Oxford University Press, pp. 59-91.

Fligstein, N. (2008) Euro-Clash: The EU, European Identity and the Future of Europe, Oxford: Oxford University Press. 
Friedman, B. (2003) 'Mediated Popular Constitutionalism' Michigan Law Review 101(8): 2596636.

Gibson, J. L., Caldeira, G. A., and Spence, L. K. (2005) 'Why Do People Accept Public Policies They Oppose? Testing Legitimacy Theory with a Survey-Based Experiment' Political Research Quarterly 58(2): 187-201.

Granger, M.-P. (2004) 'When governments go to Luxembourg...: the influence of governments on the European Court of Justice' European Law Review 29(1) 1-31.

Harding, C. and Gibbs, A. (2005) 'Why Go to Court in Europe? An Analysis of Cartel Appeals 19952004' European Law Review 30(3): 349-362.

Héritier, A., Knill, C., and S. Mingers, S. (1996) Ringing the Bells of Changes in Europe: Regulatory Competition and the transformation of the State. Britain, France, Germany, Berlin: De Gruyter.

Howse, R. L. and Teitel, R. (2010) 'Beyond Compliance: Rethinking Why International Law Really Matters' Global Policy 1(2): 127-136.

Jupille, J. and Caporaso, J. (2009) 'Domesticating discourses: European law, English judges, and political institutions' European Political Science Review 1(2): 205-228.

Kelemen, R.D. (2011) Eurolegalism: The Transformation of Law and Regulation in the European Union, Cambridge: Harvard University Press.

Komárek, J. (2011) 'Precedent in European Union Law: Reasoning with Previous Decisions of the Court of Justice’, Ph.D. dissertation, Faculty of Law, University of Oxford.

Miceli T.J. and Coşgel, M.M. (1994) 'Reputation and Judicial Decision Making' Journal of Economic Behaviour and Organisation 23(1): 31-51.

Murphy, W. F. (2007) Constitutional Democracy, Baltimore: Johns Hopkins University Press.

Nyikos, S.A. (2003) 'The Preliminary Reference Process: National Court Implementation, Changing Opportunity Structures and Litigant Desistment' European Union Politics 4(4): 397 419.

Penner, J.E. (2003) 'Legal Reasoning and the Authority of Law' 71-97 in L.H. Meyer, S. Paulson, and T. Pogge (eds), Rights, Culture, and the Law: Themes from the Legal and Political Philosophy of Joseph Raz, Oxford: Oxford University Press, pp. 71-97.

Poiares Maduro, M. (1998) We the court: the European Court of Justice and the European Economic Constitution: a critical reading of Article 30 EC, Oxford-Portland: Hart.

Rawlings, R. (1993) 'The Euro-law Game: Some Deductions from a Saga' Journal of Law and Society 20(3): 309-340.

Rogers, J. R. (2001) 'Information and Judicial Review: A Signaling Game of Legislative-Judicial Interaction' American Journal of Political Science 45(1): 84-99.

Schepel, H., and Wesseling, R. (1997) "The Legal Community: Judges, Lawyers, Officials and Clerks in the Writing of Europe' European Law Journal 3(2): 165-188.

Schauer, F. (1999) 'Incentives, Reputation and the Inglorious Determinants of Judicial Behaviour' Cincinnati Law Review 68(3): 615-636.

Slagter, T.H. (2009) 'National Parliaments and the ECJ: A View from the Bundestag' Journal of Common Market Studies 47(1): 175-197. 
Stein. E. (1981) 'Lawyers, Judges, and the Making of a Transnational Constitution' American Journal of International Law 75(10): 1-27.

Stone Sweet, A. and Brunell, T. (1998) 'The European Court and National Courts: A Statistical Analysis of Preliminary References 1961-1995' Journal of European Public Policy 5(1): 66-97.

Stone Sweet, A. and Caporaso, J. A. (1998) 'From Free Trade to Supranational Polity: The European Court and Integration', in W. Sandholtz and A. Stone Sweet (eds), European Integration and Supranational Governance, Oxford: Oxford University Press, pp. 92-133.

Terra, B. J.M. and Wattel, P. (2008) European Tax Law, Deventer: Kluwer.

Tridimas, T. and Gari, G. (2010) 'Winners and losers in Luxembourg: A statistical analysis of judicial review before the European Court of Justice and the Court of First Instance (20012005)' European Law Review 35(2): 131-73.

Vanberg, G. (2001) 'Legislative-Judicial Relations: A Game-Theoretic Approach to Constitutional Review’ American Political Science Review 45(2): 346-361. 
The Reference Points of EU Judicial Politics

Eqs 


\section{Recent LEQS papers}

Hassel, Anke. 'The paradox of liberalization - Understanding dualism and the recovery of the German political economy' LEQS Paper No. 42, September 2011

Hancké, Bob. 'Endogenous Coordination: Multinational Companies and the Production of Collective Goods in Central and Eastern Europe' LEQS Paper No. 41, August 2011

Crescenzi, Riccardo, De Filippis, Fabrizio \& Pierangeli, Fabio. 'In tandem for cohesion? Synergies and conflicts between regional and agricultural policies of the European Union' LEQS Paper No. 40, July 2011

Somek, Alexander. 'The Social Question in a Transnational Context' LEQS Paper No. 39, June 2011

Mabbett, Deborah. 'A Rights Revolution in Europe? Regulatory and judicial approaches to nondiscrimination in insurance' LEQS Paper No. 38, May 2011

Karaman, K. Kıvanç \& Pamuk, Şevket. 'Different Paths to the Modern State in Europe: The interaction between domestic political economy and interstate competition.' LEQS Paper No. 37, May 2011

Scharpf, Fritz W.. 'Monetary Union, Fiscal Crisis and the Preemption of Democracy.' Paper presented at the LEQS Annual Lecture 'Saving the Euro - at the expense of democracy in Europe?' on 12 May 2011 at the London School of Economics, LEQS Paper No. 36, May 2011

Zigante, Valentina. 'Assessing Welfare Effects of the European Choice Agenda: The case of health care in the United Kingdom.' LEQS Paper No. 35, May 2011

Hobolth, Mogens. 'European visa cooperation: interest politics and regional imagined communities.' LEQS Paper No. 34, May 2011

Monastiriotis, Vassilis. 'Regional Growth Dynamics in Central and Eastern Europe.' LEQS Paper No. 33, April 2011

Johnston, Alison. 'The Revenge of Baumol's Cost Disease?: Monetary Union and the Rise of Public Sector Wage Inflation.' LEQS Paper No. 32, March 2011

Glendinning, Simon. “Europe, for example.' LEQS Paper No. 31, March 2011

Winkler, Heinrich August. 'Greatness and Limits of the West. The History of an Unfinished Project.' LEQS Paper No. 30, February 2011

Dani, Marco. 'Assembling the fractured European consumer.' LEQS Paper No. 29, January 2011

Joerges, Christian. 'Unity in Diversity as Europe's Vocation and Conflict's Law as Europe's Constitutional Form.' LEQS Paper No. 28, December 2010

Kylstad, Ingrid. 'Turkey and the EU: A 'new' European identity in the making?' LEQS Paper No. 27, November 2010

Costa-i-Font, Joan. 'Regional Single Currency Effects on Bilateral Trade with the European Union.' LEQS Paper No. 26, October 2010

Erkan, Ozgur. 'Spain's Referendum on the European Constitutional Treaty: A Quantitative Analysis Within the Conceptual Framework of First and Second Order Elections.' LEQS Paper No. 25, June 2010 
LEQS

European Institute London School of Economics Houghton Street WC2A 2AE London

Email: euroinst.LEQS@lse.ac.uk

http://www2.lse.ac.uk/europeanInstitute/LEQS/Home.aspx

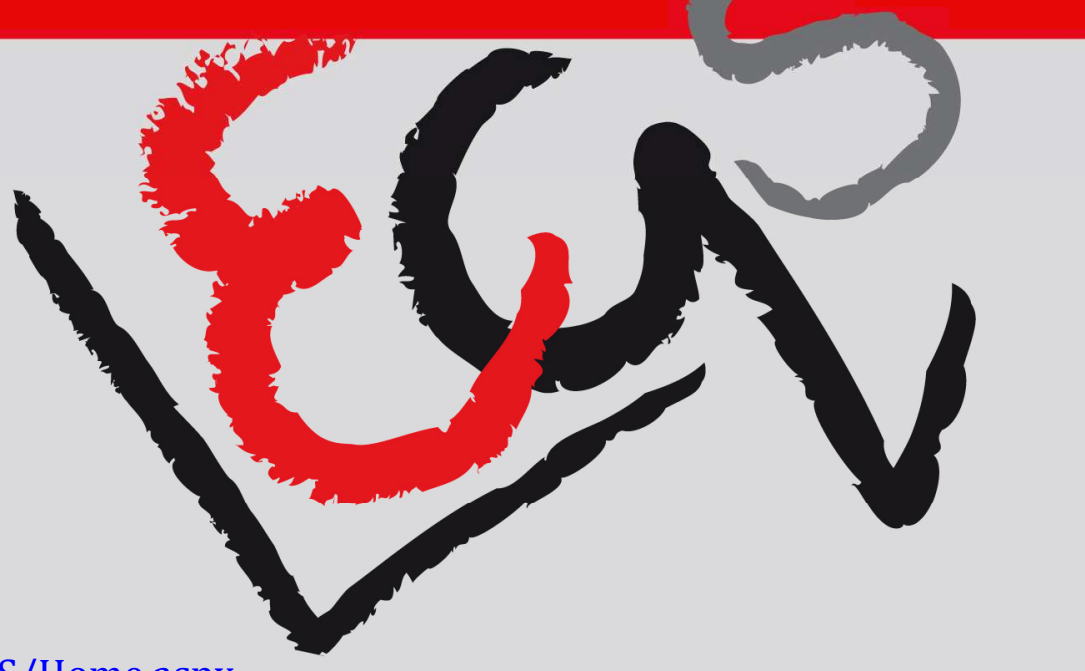

